\title{
Ultrasound-assisted enzymatic hydrolysis of broken Riceberry rice for sugar syrup production as a substrate for bacterial cellulose facial mask development
}

\author{
Thanasak Lomthong ${ }^{1 *}$ D , Sirirat Siripornvisal ${ }^{2}$, Pannida Khunnamwong ${ }^{3,4}$ \\ ${ }^{1}$ Division of Biology, Faculty of Science and Technology, Rajamangala University of Technology Thanyaburi, Pathumthani, Thailand. \\ ${ }^{2}$ Department of Microbiology, Faculty of Science and Technology, Phranakhon Si Ayutthaya Rajabhat University, Ayutthaya, Thailand. \\ ${ }^{3}$ Department of Microbiology, Faculty of Science, Kasetsart University, Bangkok, Thailand. \\ ${ }^{4}$ Biodiversity Center Kasetsart University (BDCKU), Bangkok, Thailand
}

\section{ARTICLE INFO \\ Article history: \\ Received on: August 22, 2021 \\ Accepted on: October 04, 2021 \\ Available Online: February 15, 2022}

\section{Key words:}

Broken Riceberry rice, facial mask product, ultrasound, bacterial cellulose, enzymatic hydrolysis

\begin{abstract}
Broken Riceberry rice powder was saccharified by ultrasound-assisted enzymatic hydrolysis for the production of sugar syrup containing phenolic compounds. The results showed that total soluble solid (TSS) content at $17.0 \pm 0.5^{\circ}$ Brix was obtained when sonicating broken Riceberry rice powder $(250 \mathrm{~g} / \mathrm{l})$ with a low-temperature amylase at $60 \%$ amplitude for 20 minutes and subsequent hydrolysis at $50^{\circ} \mathrm{C}$ for 12 hours. Upscaled hydrolysis in a 5.01 reactor gave the highest TSS content and total phenolic content (TPC) at $16.33 \pm 0.29^{\circ}$ Brix and $5.63 \pm$ $0.12 \mathrm{mg} \mathrm{GAE} / \mathrm{g}$ sample, respectively. The obtained Riceberry syrup was used for bacterial cellulose (BC) fermentation using Komagataeibacter xylinus AGR 60, which was incubated at room temperature for 4 days and yielded $4.80 \pm 0.30 \mathrm{~mm}$ of thickness with $2.51 \pm 0.24 \mathrm{~g}$ of dry weight equivalent to $3.14 \pm 0.30 \mathrm{~g} / \mathrm{l} / \mathrm{day}$. The physical structure of the obtained BC showed a crowded cellulose network, which showed the potential for water holding capacity of a facial mask sheet product. The five facial mask formulations were tested and showed significant results for the storage ability. This study provided an innovative product from the low-cost agricultural crop through the biotechnological process and showed the potential for further application at the commercial level.
\end{abstract}

\section{INTRODUCTION}

Broken Riceberry rice was defined as a low-cost agricultural crop in Thailand, usually obtained from the polished rice production process, which showed an irregular size and shape compared to the regular Riceberry rice product [1,2]. Currently, broken Riceberry rice was applied for the development of various products due to its low cost and has a chemical composition similar to regular rice grain, glutenfree bread [3], healthy dark chocolates [4], and vinegar [2]. However, to the best of our knowledge, there are few reports on using a lowcost broken Riceberry rice as a substrate for bacterial cellulose (BC) production, particularly $\mathrm{BC}$ for cosmeceutical products.

\footnotetext{
*Corresponding Author

Thanasak Lomthong, Division of Biology, Faculty of Science and Technology, Rajamangala University of Technology Thanyaburi, Pathumthani, Thailand.E-mail: thanasak_l@ rmutt.ac.th
}

$\mathrm{BC}$ is a polymer of $\beta-1,4$ linkages of glucose molecules which can be produced from some bacterial species. Currently, Noree et al. [5] reported the production of $\mathrm{BC}$ from colored rice by Komagataeibacter xylinus AGR 60, while Moukamnerd et al. [6] produced the BC from Komagataeibacter nataicola TISTR 2661 using agrowaste as a carbon source. BC has good characteristics like high porosity, strong water absorption, high water holding capacity, high mechanical strength, and good biocompatibility, as Pang et al. [7] reported. Up to date, BC is widely used for application in various fields such as food, packaging, and biomedical [8]. However, fewer data were recorded for application as a facial mask in the cosmetic field.

Generally, the most usually used conventional methods include soxhlet extraction, maceration, and hydrodistillation [9]. However, these methods have certain limitations, such as low yield and excessive solvents in the crude extract. Recently, Noree et al. [5] reported the enzymatic degradation process for producing rice 
syrup containing phenolic compounds from broken Riceberry rice. At the same time, Thamapan et al. [10] reported the application of ultrasound-assisted extraction (UAE) to extract sweetening compounds from sweet Thai plants.

Ultrasound-assisted enzymatichydrolysis has received considerable attention for extraction and hydrolysis of various substrates due to improved mass transfer, which mainly results from ultrasonic cavitation [11-13]. Moreover, the ultrasound treatment also destroys the substrate's crystalline structure, increasing hydrolysis efficiency [14]. From a previous study, Lunelli et al. [11] reported that ultrasound irradiation enhances the production of fermentable sugar from sugarcane bagasse, while Wang et al. [13] enhanced the hydrolysis of potato starch by ultrasound-assisted enzymatic hydrolysis with glucoamylase, which showed the potential for applying this method for improving the saccharification process. Therefore, this study aimed to investigate the saccharification and extraction of sugar syrup and phenolic compounds from broken Riceberry rice using ultrasound-assisted enzymatic hydrolysis method and used the obtained hydrolysis product as a substrate for BC fermentation. The potential of facial mask production from the obtained $\mathrm{BC}$ with five formulations with their shelflife was also investigated.

\section{MATERIALS AND METHODS}

\subsection{Substrate, Enzyme, and Microorganism}

Broken Riceberry rice with irregular size and shape was obtained from the Nong Luang Enterprise Group, Khampangphet Province, Thailand, as reported by Sangngern et al. [2]. The rice grain was made to powder by an electric grinder and stored in the plastic box at dry condition until use. The liquid $\alpha$-amylase (EC 3.2.1.1), which was produced from Bacillus subtilis (iKnowZyme ${ }^{\circledR}$ LTAA, HS Code 3507.9090), was obtained from the Reach Biotechnology Co., Ltd., Thailand, and stored at $-20^{\circ} \mathrm{C}$. Cellulose-producing bacteria $K$. xylinus AGR 60, a potent strain for BC production, were obtained from the Institute of Food Research and Product Development, Kasetsart University, Thailand. AGR 60 strain was grown in the coconut juice inoculum medium, as Noree et al. [5] reported. Herbal extracts, including lotus stamen (Nelumbo nucifera), banana peel (Musa sapientum), ginger rhizome (Zingiber officinale), and Sa-Khan (Piper interruptum Opiz.), were purchased from the SK Herb Company, Thailand, and stored at $-20^{\circ} \mathrm{C}$ until use.

\subsection{Ultrasound-Assisted Enzymatic Hydrolysis of Broken Riceberry Powder}

The broken Riceberry powder at $250 \mathrm{~g} / \mathrm{l}$ was added to the $250 \mathrm{ml}$ Erlenmeyer flask containing $50 \mathrm{ml}$ of enzyme solution $(2.0 \% \mathrm{v} / \mathrm{v}$ in distilled water) [2]. The suspension was preheated at $50^{\circ} \mathrm{C}$ in a water bath for 5 minutes before being treated with the ultrasound sonicator. The ultrasound-assisted enzymatic hydrolysis was conducted using an ultrasonic probe processor (Vibra-Cell Ultrasonic Processors 130 Watt and $20 \mathrm{kHz}$, USA) with a 5.0 $\mathrm{mm}$ ultrasonic horn creating $20 \mathrm{kHz}$ frequency. The effect of ultrasonic intensity on the hydrolysis of broken Riceberry powder was investigated by varying the sonication amplitude at $30 \%-80 \%$
[14] for 10 minutes and continued incubation at $50^{\circ} \mathrm{C}$ for 12 hours. The samples were taken at 1, 3, 6, 9, and 12 hours during the incubation to determine total soluble solid (TSS) content. The optimum sonication amplitude was used to investigate the optimum sonication time by varying the experiments at different sonication times of 10-40 minutes [13] and subsequently incubated at $50^{\circ} \mathrm{C}$ for 12 hours as described above. The optimum sonication amplitude and sonication time were used for upscale in a 5.01 glass jar chamber $(18 \times 18 \times 28 \mathrm{~cm})$ with a 3.01 working volume [2]. The samples at different times were taken to determine TSS content and total phenolic content (TPC). The sugar profile of the broken Riceberry syrup was analyzed by high-performance liquid chromatography using a refractive index detector as reported by $\mathrm{Lu}$ et al. [15]. Glucose, maltose, and maltotriose were used as standards. The morphological changes in native and digested broken Riceberry rice powder before and after ultrasound-assisted enzymatic hydrolysis were investigated using scanning electron microscopy (SEM) (Model SU8020; Hitachi, Tokyo, Japan) as described by Lomthong et al. [16].

\subsection{BC Fermentation}

The BC fermentation was performed in a plastic tray $(15 \times 25 \times$ $6 \mathrm{~cm}$ ) with $200 \mathrm{ml}$ of working volume. The fermentation medium was comprised of $100 \mathrm{ml}$ of the obtained broken Riceberry syrup $\left(8.0^{\circ}\right.$ Brix $), 100 \mathrm{ml}$ of coconut water $\left(4.0^{\circ}\right.$ Brix $), 2.0 \mathrm{~g}$ glucose,

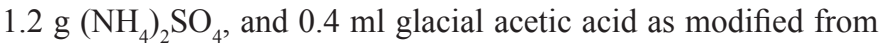
the method of Noree et al. [5] using 10\% (v/v) of K. xylinus AGR 60 as a starter culture. The fermentation was incubated for 4 days at room temperature. The obtained $\mathrm{BC}$ was boiled in the tap water at $100^{\circ} \mathrm{C}$ for 30 minutes to remove the acetic acid and characterize the structure by SEM (Model SU8020; Hitachi, Tokyo, Japan) as described above. The heavy metals and contaminated pathogens were determined according to the Thailand Standard of Cosmetic Act B.E. 2558 (2015) and Notification of Ministry of Industry Announcement No. 4462 by the Central Laboratory (Thailand) Co., Ltd., using the in-house method based on AOAC (2019) and USP 38/NF 33: 2015.

\subsection{BC Facial Mask Formulation}

The obtained $\mathrm{BC}$ facial mask was used to develop five formulations to elucidate the potential as a commercial product. The BC facial mask sheet $(6.0 \times 10.0 \mathrm{~cm})$ after being sterilized at $121^{\circ} \mathrm{C}$ for 10 minutes was immersed in the five bioactive compound solutions, including each $20 \mathrm{mg} / \mathrm{ml}$ of broken Riceberry syrup, lotus stamen, banana peel, ginger rhizome, and Sa-Khan. All the sheets were incubated at $25^{\circ} \mathrm{C}$ for 28 days and the microbiological and physical changes were determined every 7 days. The $\mathrm{BC}$ sample immersed in the distilled water was used as a control.

\subsection{Analysis}

TSS content was investigated using a refractometer (RA-250WE, Kyoto Electronics, Kyoto, Japan) [2]. The total phenolic content (TPC) of broken Riceberry extract was determined by the Folin-Ciocalteu method described by Butsat and Siriamornpun [17]. Gallic acid was used and calculated as mg gallic acid equivalents per $g$ rice sample (mg GAE/g sample). 
Total plate count (TPC) was determined by spreading the appropriate dilution of samples on the nutrient agar plate and incubated at $30^{\circ} \mathrm{C}$ for 48 hours.

All statistical analyses were analyzed using SPSS for Windows version 20 (SPSS Inc., USA). Differences among the mean values were tested using the least significant difference multiple range test, and significance was taken at the $p<0.05$ level $[5,16]$.

\section{RESULTS AND DISCUSSION}

\subsection{Ultrasound-Assisted Enzymatic Hydrolysis of Broken Riceberry Powder}

Broken Riceberry rice was reported to contain high content of starch $(65.77 \% \pm 0.94 \%)$ which showed the potential for application as a substrate for sugar syrup production [2]. The effects of sonication power (amplitude) and sonication time on the TSS contents at different incubation times are shown in Figure 1. The maximum sugar syrup production at $17.0 \pm 0.5^{\circ} \mathrm{Brix}$ with equivalent to $1.46^{\circ} \mathrm{Brix} /$ hour was found when sonicated at $60 \%$ amplitude power for 20 minutes and continued incubating at $50^{\circ} \mathrm{C}$ for 12 hours. The increase of percent amplitude could increase the yield of the sugar syrup until the optimum point $(60 \%)$. Higher this point of percent amplitude, the hydrolysis yield was decreased (Fig. 1a). Jadhav and Gogate [18] and Wang et al. [13] reported that ultrasonic cavitation could affect the enzyme conformation, promoting enzyme-substrate binding. However, the higher optimum point may provide a negative effect on the enzyme conformation. From the previous study, Sangngern et al. [2] reported the hydrolysis broken Riceberry powder by iKnowZyme ${ }^{\mathbb{R}}$ LTAA, which obtained $13^{\circ}$ Brix $\left(1.08^{\circ}\right.$ Brix/hour $)$ of TSS after being incubated at $50^{\circ} \mathrm{C}$ for 12 hours. At the same time, Thamapan et

(a)
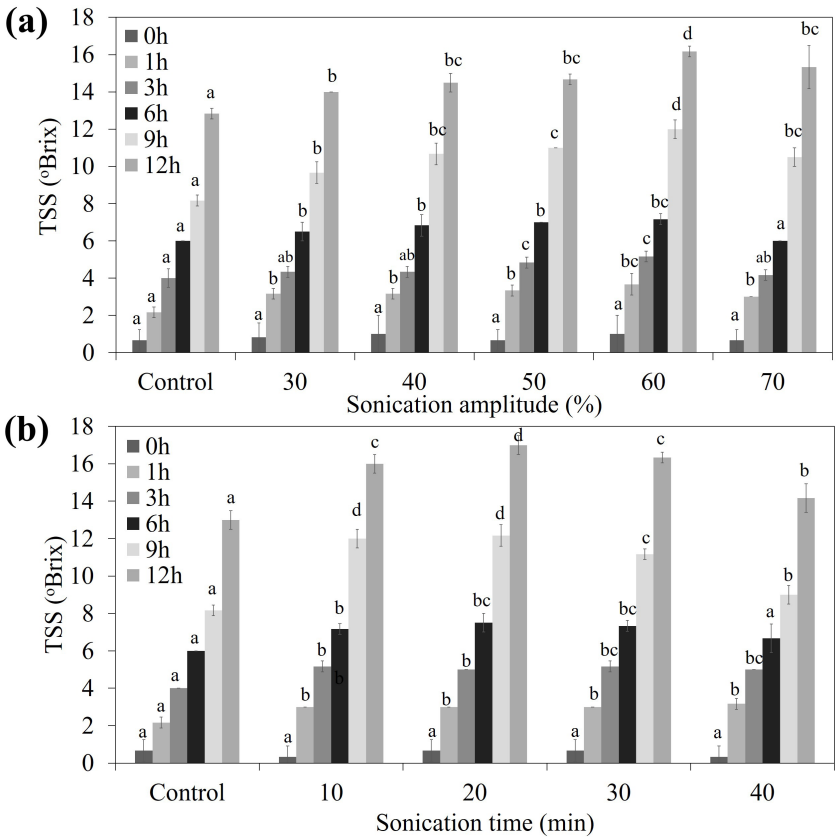

Figure 1: Effect of sonication amplitude (a) and sonication time (b) on the sugar syrup production from broken Ricebery rice by ultrasound-assisted enzyme hydrolysis. al. [10] reported applying UAE to extract sweetening compounds from sweet Thai plants. Airlangga et al. [14] studied the effect of amplitude power on the structure of cassava starch granule and found that ultrasound treatment destruction the crystalline structure and changes it into a soluble form. The destruction of the crystalline structure of starch supported the entering of water and enzyme to the starch granule, letting granule swelling, and breaking the glycosidic bond. Ultrasound-assisted enzymatic hydrolysis further improves the mass transfer from the collage of microbubbles which would uniform the mixture, showing notable enhancement of mass transfer, which improves the affinity of enzymes and substrate [13]. The collapse of cavitation bubbles induced the high-pressure gradients and high local velocities, causing damage to the starch granules [19]. Airlangga et al. [14] also reported that amplitude affects the ultrasound intensity and the high-intensity increase in the number and size of the bubble destroyed and reduced crystalline starch structure. This study revealed that ultrasound-assisted enzymatic hydrolysis improved the hydrolysis of broken Riceberry powder, which increased up to 1.31 -fold as compared to the previous study [2]. The upscale hydrolysis was performed in a 5.01 glass jar chamber as described in the method. The maximum TSS and TPC were found at $16.33 \pm$ $0.29^{\circ}$ Brix and $5.63 \pm 0.12 \mathrm{mg} \mathrm{GAE} / \mathrm{g}$ sample, respectively, after incubated at $50^{\circ} \mathrm{C}$ for 12 hours (Fig. 2). The sugar profile of the broken Riceberry syrup at different hydrolysis times is shown in Table 1. Glucose was the major product from the hydrolysis with less amount of maltose and maltotriose.

Scanning electron micrographs of native and digested broken Riceberry powder are shown in Figure 3. The native broken Riceberry powder showed a slightly globular shape with a slightly rough surface (Fig. 3a). While the Riceberry granule, after ultrasound with iKnowZyme ${ }^{\circledR}$ LTAA at $60 \%$ amplitude for 20 minutes, found granule swelling and some fragments were occured from the destruction of the rice granule (Fig. 3b). Figure $3 \mathrm{c}$ showed the remaining rice granule after digested with ultrasound-assisted enzyme hydrolysis at $50^{\circ} \mathrm{C}$ for 12 hours, which found loss of structure, form the pit and deep hole on the Riceberry granule. Ultrasound-assisted enzymatic hydrolysis approach improved the hydrolysis efficiency of broken Riceberry substrate and showed the potential for application in the future.

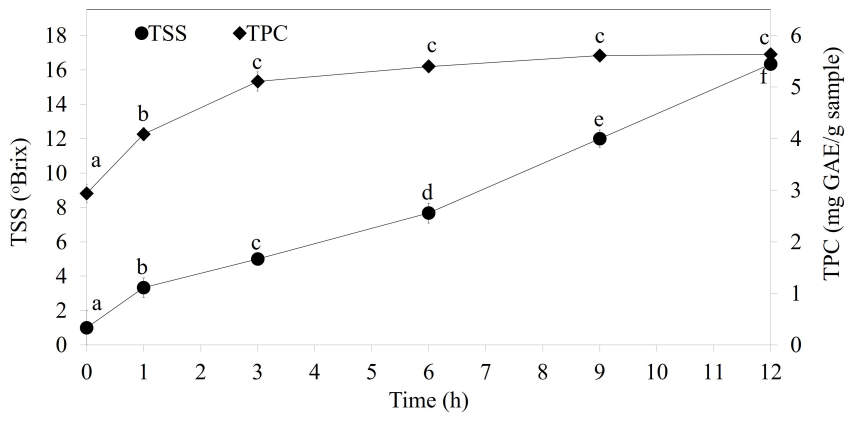

Figure 2: Time course of sugar syrup production (TSS) and total phenolic content (TPC) from the hydrolysis of broken Ricebery rice by ultrasound-assisted enzyme hydrolysis. Different lowercase letters indicate significant $(p<0.05)$ differences among means. 
Table 1: Soluble end products of broken Riceberry powder hydrolysis by ultrasound-assisted enzyme hydrolysis at different incubation times.

\begin{tabular}{lrrrrr}
\multicolumn{1}{c}{ Product } & $\mathbf{1}$ hour & $\mathbf{3}$ hours & $\mathbf{6}$ hours & 9 hours & $\mathbf{1 2}$ hours \\
\cline { 2 - 2 } & $20.61 \pm 1.88^{\mathrm{a}}$ & $42.27 \pm 2.11^{\mathrm{b}}$ & $57.30 \pm 3.35^{\mathrm{c}}$ & $99.67 \pm 7.02^{\mathrm{d}}$ & $128.43 \pm 7.21^{\mathrm{e}}$ \\
Maltose & $8.61 \pm 1.04^{\mathrm{ab}}$ & $7.05 \pm 0.64^{\mathrm{a}}$ & $10.53 \pm 0.97^{\mathrm{ab}}$ & $10.37 \pm 1.52^{\mathrm{c}}$ & $16.09 \pm 1.44^{\mathrm{d}}$ \\
Maltotriose & $3.35 \pm 0.26^{\mathrm{a}}$ & $2.21 \pm 0.49^{\mathrm{b}}$ & $1.55 \pm 0.29^{\mathrm{b}}$ & $1.86 \pm 0.39^{\mathrm{c}}$ & $1.46 \pm 0.22^{\mathrm{bc}}$ \\
Total & $32.57 \pm 2.59^{\mathrm{a}}$ & $51.53 \pm 2.66^{\mathrm{b}}$ & $69.38 \pm 3.46^{\mathrm{c}}$ & $111.90 \pm 6.90^{\mathrm{d}}$ & $145.98 \pm 8.86^{\mathrm{e}}$ \\
\hline
\end{tabular}

Values are averages of three determinations.

Different letters within the same row indicate a statistical difference at $p<0.05$.

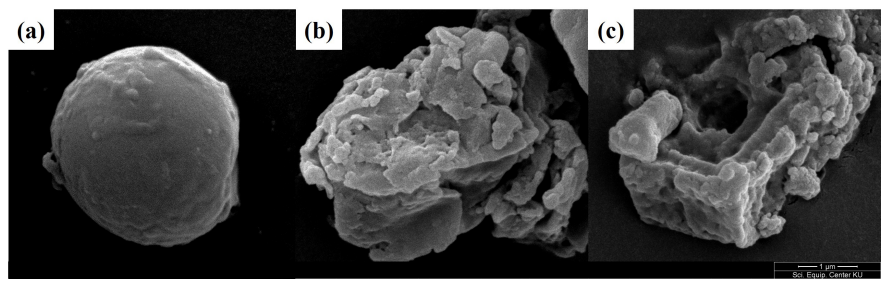

Figure 3: Scanning electron micrographs of native and digested broken Ricebery granules. (a) Native granule, (b) after ultrasound with iKnowZyme ${ }^{\circledR}$ LTAA at $60 \%$ amplitude for 20 minutes, and (c) digested with ultrasound-assisted enzyme hydrolysis and incubated at $50^{\circ} \mathrm{C}$ for 12 hours.

\subsection{BC Fermentation}

The parameters for BC fermentation from broken Riceberry syrup by $K$. xylinus AGR 60 are shown in Table 2. The thickness of obtained $\mathrm{BC}$ was found at $4.80 \pm 0.30 \mathrm{~mm}$ with dry weight at 2.51 $\pm 0.24 \mathrm{~g}$. The BC production $(p)$ was found at $12.55 \pm 1.20 \mathrm{~g} / 1$ with $\mathrm{BC}$ production rate $\left(R_{\mathrm{p}}\right)$ at $3.14 \pm 0.30 \mathrm{~g} / \mathrm{l} /$ day. To compare with other studies, Moukamnerd et al. [6] reported the production $(p)$ values of $\mathrm{BC}$ from various substrates which recorded in the range of $0.31 \pm 0.07$ to $2.10 \pm 0.20 \mathrm{~g} / \mathrm{l}$, indicating that broken Riceberry syrup in this study could be used as a substrate for BC production as a choice for commercial production in the future. The TSS of the culture medium was changed from $5.00 \pm 0.00^{\circ}$ Brix to 4.83 $\pm 0.29^{\circ}$ Brix while $\mathrm{pH}$ was decreased from $4.48 \pm 0.02$ to 3.53 \pm 0.15 . The obtained BC from broken Riceberry syrup showed a slightly light pink color, as shown in Figure $4 \mathrm{a}$, while Figure $4 \mathrm{~b}$ showed the cellulose fiber of BC under SEM. The SEM showed that the obtained $\mathrm{BC}$ formed crowed cellulose network and less free space, which showed the potential for water holding capacity for a facial mask sheet property product. The obtained $\mathrm{BC}$ was further used for the development of $\mathrm{BC}$ facial mask products.

Table 2: BC production parameters from broken Riceberry syrup by K. xylinus AGR 60 at room temperature for 4 days.

\begin{tabular}{ll} 
Parameter & Result \\
BC thickness $(\mathbf{m m})$ & $4.80 \pm 0.30$ \\
Dry weight $(\mathbf{g})$ & $2.51 \pm 0.24$ \\
Total soluble solid (Brix) & $4.83 \pm 0.29$ \\
pH & $3.53 \pm 0.15$ \\
BC production $\left(\boldsymbol{p}, \mathbf{g}^{*} / \mathbf{l}\right)$ & $12.55 \pm 1.20$ \\
BC production rate $\left(\boldsymbol{R}_{\mathbf{p}}, \mathbf{g}^{*} / / /\right.$ day $)$ & $3.14 \pm 0.30$ \\
\hline
\end{tabular}

Values are averages of three determinations.

*Based on dry matter.

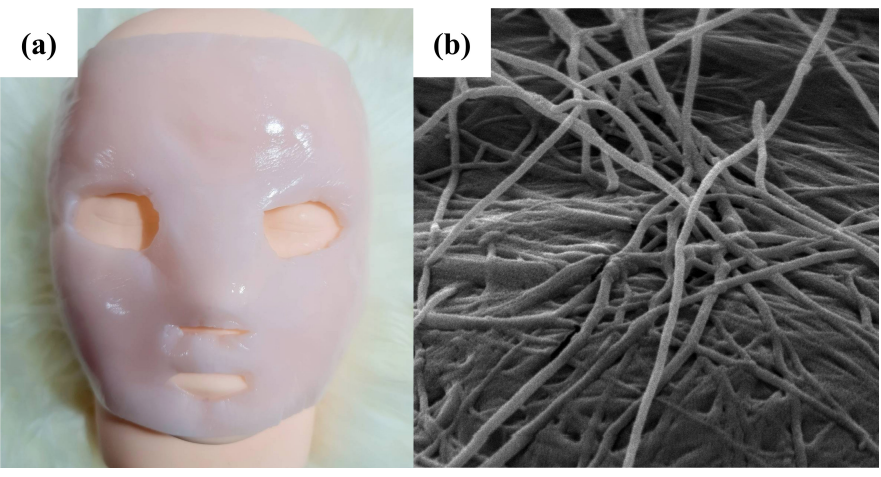

Figure 4: Photograph (a) and scanning electron micrograph (b) of the BC facial mask obtained from the fermentation of $K$. xylinus AGR 60.

The heavy metals and contaminated pathogens were determined as described above. The results are shown in Table 3. The arsenic $(\mathrm{As})$, lead $(\mathrm{Pb})$, and tin $(\mathrm{Sn})$ were not found in the BC product, while copper $(\mathrm{Cu})$, mercury $(\mathrm{Hg})$, and zinc $(\mathrm{Zn})$ were found in a small amount with less than the standard value (Table 3 ). In the case of microbial properties, the TPC, mold, and yeast showed amount under the standard according to the Thailand standard of Cosmetic Act B.E. 2558 (2015) and Notification of Ministry of Industry Announcement No. 4462 which not found the pathogenic

Table 3: Analysis of heavy metals and contaminated pathogens in bacterial cellulose facial mask prototype.

$\begin{array}{lcc}\text { Analysis } & \text { Result } & \text { Standard value } \\ \text { Heavy metal } & & \\ \text { Arsenic (As) } & \mathrm{ND} & <2.0 \mathrm{mg} / \mathrm{kg} \\ \text { Copper (Cu) } & 0.157 \pm 0.01 \mathrm{mg} / \mathrm{kg} & <2.0 \mathrm{mg} / \mathrm{kg} \\ \text { Lead (Pb) } & \mathrm{ND} & <1.0 \mathrm{mg} / \mathrm{kg} \\ \text { Mercury (Hg) } & <0.020 \mathrm{mg} / \mathrm{kg} & <0.5 \mathrm{mg} / \mathrm{kg} \\ \text { Tin (Sn) } & \mathrm{ND} & <250 \mathrm{mg} / \mathrm{kg} \\ \text { Zinc (Zn) } & 1.063 \pm 0.04 \mathrm{mg} / \mathrm{kg} & <100 \mathrm{mg} / \mathrm{kg} \\ \text { Microorganism } & \mathrm{ND} & \\ \text { Pseudomonas aeruginosa } & \mathrm{ND} & \mathrm{ND} \\ \text { Staphylococcus aureus } & \mathrm{ND} & \mathrm{ND} \\ \text { Candida albicans } & <10 \mathrm{CFU} / \mathrm{g} & \mathrm{ND} \\ \text { Total plate count } & <100 \mathrm{CFU} / \mathrm{g} & <500 \mathrm{CFU} / \mathrm{g} \\ \text { Total mold } & <100 \mathrm{CFU} / \mathrm{g} & <500 \mathrm{CFU} / \mathrm{g} \\ \text { Total yeast } & & \end{array}$


Table 4: Total plate count of the $\mathrm{BC}$ samples during incubation at $25^{\circ} \mathrm{C}$ for 28 days with different crude extracts.

\begin{tabular}{lccccc} 
Crude extract & \multicolumn{3}{c}{ Total plate count (log CFU/g) } \\
$\mathbf{( 2 0} \mathbf{~ m g / m l )}$ & Day 0 & Day 7 & Day 14 & Day 21 & Day 28 \\
Ginger & $0.00 \pm 0.00^{\mathrm{a}}$ & $0.00 \pm 0.00^{\mathrm{a}}$ & $0.00 \pm 0.00^{\mathrm{a}}$ & $0.00 \pm 0.00^{\mathrm{a}}$ & $0.00 \pm 0.00^{\mathrm{a}}$ \\
Sa-Khan & $0.00 \pm 0.00^{\mathrm{a}}$ & $0.00 \pm 0.00^{\mathrm{a}}$ & $0.00 \pm 0.00^{\mathrm{a}}$ & $0.00 \pm 0.00^{\mathrm{a}}$ & $3.68 \pm 0.10$ \\
Lotus stamen & $0.00 \pm 0.00^{\mathrm{a}}$ & $0.00 \pm 0.00^{\mathrm{a}}$ & $0.00 \pm 0.00^{\mathrm{a}}$ & $0.00 \pm 0.00^{\mathrm{a}}$ & $0.00 \pm 0.00^{\mathrm{a}}$ \\
Banana peel & $0.00 \pm 0.00^{\mathrm{a}}$ & $0.00 \pm 0.00^{\mathrm{a}}$ & $7.17 \pm 0.01^{\mathrm{b}}$ & TNTC & TNTC \\
Riceberry syrup & $0.00 \pm 0.00^{\mathrm{a}}$ & $0.00 \pm 0.00^{\mathrm{a}}$ & $0.00 \pm 0.00^{\mathrm{a}}$ & $0.00 \pm 0.00^{\mathrm{a}}$ & $0.00 \pm 0.00^{\mathrm{a}}$ \\
Distilled water (control) & $0.00 \pm 0.00^{\mathrm{a}}$ & $0.00 \pm 0.00^{\mathrm{a}}$ & $0.00 \pm 0.00^{\mathrm{a}}$ & $0.00 \pm 0.00^{\mathrm{a}}$ & $5.25 \pm 0.07^{\mathrm{b}}$ \\
\hline
\end{tabular}

Values are averages of three determinations.

TNTC $=$ Too numerous to count.

Different letters within the same column indicate a statistical difference at $p<0.05$.

bacteria of Pseudomonas aeruginosa, Staphylococcus aureus, and Candida albicans in the sample.

\subsection{BC Facial Mask Formulation}

The $\mathrm{BC}$ sheet reported the possibility for application in the cosmetic industry, such as facial masks, facial scrub, and contact lenses [20]. In this study, the obtained BC from broken Riceberry syrup was incorporated with five kinds of crude extracts as described above. All extracts were reported to contain antioxidant activity, including ginger [21], Sa-Khan [22], broken Riceberry syrup [2], lotus stamen [23], and banana peel [24] which are interesting to apply as ingredients for $\mathrm{BC}$ facial mask production. In this study, we studied the shelf life at $25^{\circ} \mathrm{C}$, which aimed to evaluate the possibility for storage of the product without a refrigerator which could reduce the energy consumption and cost of operation. The microbial change (TPC) of the BC facial mask with five formulations is shown in Table 4. The results showed that the formula containing ginger, lotus stamen, and broken Riceberry syrup did not show microbial growth during 28 days of incubation, while the formula containing Sa-Khan was found at $3.68 \pm 0.10 \mathrm{log} \mathrm{CFU} / \mathrm{g}$ of the total plate count after being incubated at $25^{\circ} \mathrm{C}$ for 28 days. The $\mathrm{BC}$ facial mask in banana peel extract found the microbial growth higher than the standard from 14 days of incubation. In the case of physical characteristics, the BC sample in the banana peel extract showed loss of the physical quality from the 14 days of incubation, but other formulas show the same physical characteristic (Table $5)$. The results revealed the potential for developing $\mathrm{BC}$ facial

Table 5: Physical changes of $\mathrm{BC}$ facial mask samples were incubated at $25^{\circ} \mathrm{C}$ for 28 days with different crude extracts.

\begin{tabular}{lccccc}
\multicolumn{5}{c}{ Crude extract } & \multicolumn{5}{c}{ Observed physical characteristic } \\
\multicolumn{1}{c}{$(\mathbf{2 0} \mathrm{mg} / \mathrm{ml})$} & Day 0 & Day 7 & Day 14 & Day 21 & Day 28 \\
Ginger & - & - & - & - & - \\
Sa-Khan & - & - & - & - & - \\
Lotus stamen & - & - & - & - & - \\
Banana peel & - & - & + & ++ & ++ \\
Riceberry syrup & - & - & - & - & + \\
Distilled water (control) & - & - & + & ++ & ++ \\
\hline$-=$ Do not changed. & & & & & \\
+ + Some sediments were found in the sample. \\
$++=$ Appearance of the wrinkle and the growth of mold were found.
\end{tabular}

masks from the low-cost agricultural crop of broken Riceberry rice as a commercial product which required further evaluation as cosmetic products in the future.

\section{CONCLUSION}

Broken Riceberry rice was a cheap material used as a low-cost substrate for producing various kinds of products. In this study, the broken Riceberry powder was used as a substrate for sugar syrup production by ultrasound-assisted enzyme hydrolysis at below gelatinization temperature and used as a substrate for a novel BC facial mask production. The obtained $\mathrm{BC}$ facial mask from broken Riceberry rice showed the potential as a cosmetic product due to its physical and microbiological properties. The shelf life of the $\mathrm{BC}$ facial mask with five formulations was developed and the possibility for application as a commercial product was elucidated in the future.

\section{ACKNOWLEDGMENTS}

This research was supported by the Institute of Research and Development Rajamangala University of Technology, Thanyaburi (DRF63D0606).

\section{AUTHOR CONTRIBUTIONS}

All authors made substantial contributions to conception and design, acquisition of data, or analysis and interpretation of data; took part in drafting the article or revising it critically for important intellectual content; agreed to submit to the current journal; gave final approval of the version to be published; and agreed to be accountable for all aspects of the work. All the authors are eligible to be an author as per the international committee of medical journal editors (ICMJE) requirements/guidelines.

\section{CONFLICTS OF INTEREST}

The authors report no financial or any other conflicts of interest in this work.

\section{ETHICAL APPROVALS}

This study does not involve experiments on animals or human subjects. 


\section{PUBLISHER'S NOTE}

This journal remains neutral with regard to jurisdictional claims in published institutional affiliation.

\section{REFERENCES}

1. Luang-In V, Yotchaisarn M, Somboonwatthanakul I, Deeseenthum S. Bioactivities of organic riceberry broken rice and crude riceberry rice oil. Thai J Pharmaceu Sci 2018;42:161-16.

2. Sangngern N, Puangnark T, Nguansangiam W, Saithong $P$, Kitpreechavanich V, Lomthong T. Production and development of vinegar fermentation from broken Riceberry rice using raw starchdegrading enzyme hydrolysis. 3 Biotech 2020;10:1-9.

3. Rakkhumkaew N, Boonsri Y, Sukchum A. Utilization of small broken riceberry flour in gluten-free bread. Food Sci Technol Int 2019;25:515-22.

4. Ngamdee P, Jamkrajang S, Yankin S. Development and study on physical and sensory properties of dark chocolates fortified with anthocyanin from broken Riceberry rice. RMUTP Sci J 2020;14:4556.

5. Noree S, Tongdang C, Sujarit K, Chamdit S, Thongpool V, Trakarnpaiboon S, et al. Application of raw starch degrading enzyme from Laceyella sacchari LP175 for development of bacterial cellulose fermentation using colored rice as substrate. 3 Biotech 2021;11: 1-11.

6. Moukamnerd C, Ounmuang K, Konboa N, Insomphun C. Bacterial cellulose production by Komagataeibacter nataicola TISTR 2661 by agro-waste as a carbon source. Chiang Mai J Sci 2020;47:16-27.

7. Pang M, Huang Y, Meng F, Zhuang Y, Liu H, Du M, et al. Application of bacterial cellulose in skin and bone tissue engineering. Eur Polym J 2020;122:109365.

8. Esa F, Tasirin SM, Abd Rahman N. Overview of bacterial cellulose production and application. Agric Agric Sci Procedia 2014; 2:113-119.

9. Azmir J, Zaidul ISM, Rahman MM, Sharif KM, Mohamed A, Sahena $\mathrm{F}$, et al. Techniques for extraction of bioactive compounds from plant materials: a review. J Food Eng 2013;117:426-36.

10. Thamapan K, Laohakunjit N, Kerdchoechuen O, Vongsawasdi P, Mingvanish W. Ultrasound-assisted extraction for simultaneous quantitation of potential sweetening compounds from derris reticulata aqueous extracts: a response surface methodology approach. J Food Meas Charact 2021;15:2251-63.

11. Lunelli FC, Sfalcin P, Souza M, Zimmermann E, Dal Prá V, Foletto EL, et al. Ultrasound-assisted enzymatic hydrolysis of sugarcane bagasse for the production of fermentable sugars. Biosyst Eng 2014;124:24-8.

12. Prajapat AL, Subhedar PB, Gogate PR. Ultrasound assisted enzymatic depolymerization of aqueous guar gum solution. Ultrason Sonochem 2016;29:84-92.

13. Wang D, Ma X, Yan L, Chantapakul T, Wang W, Ding T, et al. Ultrasound assisted enzymatic hydrolysis of starch catalyzed by glucoamylase: investigation on starch properties and degradation kinetics. Carbohydr Polym 2017;175:47-54.
14. Airlangga B, Erlangga D, Solikhah LKM, Puspasari F, Gunardi I, Sumarno. Effect of amplitude on ultrasound treatment for reducing sugar production from cassava starch. AIP Conf Proc 2019;1:020073.

15. Lu Y, Warner R, Sedlak M, Ho N, Mosier NS. Comparison of glucose/ xylose cofermentation of poplar hydrolysates processed by different pretreatment technologies. Biotechnol Progr 2009;25:349-56.

16. Lomthong T, Netprasom P, Kancharu N, Jitmala K, Areesirisuk A, Trakarnpaiboon S, et al. Very high gravity (VHG) bioethanol production using modified simultaneous saccharification and fermentation of raw cassava chips with molasses by Kluyveromyces marxianus DMKU-KS07. Waste Biomass Valori 2021;12:3683-93.

17. Butsat S, Siriamornpun S. Antioxidant capacities and phenolic compounds of the husk, bran and endosperm of Thai rice. Food Chem 2010;119:606-13

18. Jadhav SH, Gogate PR. Intensification in the activity of lipase enzyme using ultrasonic irradiation and stability studies. Ind Eng Chem Res 2014;53:1377-85.

19. HerCeg IL, Jambrak AR, ŠubArIć D, Brnčić M, Brnčić SR, Badanjak $\mathrm{M}$, et al. Texture and pasting properties of ultrasonically treated corn starch. Czech J Food Sci 2010;28:83-93.

20. Ullah H, Santos HA, Khan T. Applications of bacterial cellulose in food, cosmetics and drug delivery. Cellulose 2016;23:2291-314.

21. Ali AMA, El-Nour MEM, Yagi SM. Total phenolic and flavonoid contents and antioxidant activity of ginger (Zingiber officinale Rosc.) rhizome, callus and callus treated with some elicitors. J Genet Eng Biotechnol 2018;16:677-82.

22. Daorueang D. Antioxidant activity and effect of Sa-khan (Piper, Piperaceae) on the normal human proximal tubular epithelial cell line. NUJST 2020;28:29-35.

23. Tungmunnithum D, Kongsawadworakul P, Hano C. A cosmetic perspective on the antioxidant flavonoids from Nymphaea lotus L. Cosmetics 2021;8:12.

24. Hanafy SM, Abd El-Shafea YM, Saleh WD, Fathy HM. Chemical profiling, in vitro antimicrobial and antioxidant activities of pomegranate, orange and banana peel-extracts against pathogenic microorganisms. J Genet Eng Biotechnol 2021;19:1-10.

How to cite this article:

Lomthong T, Siripornvisal S, Khunnamwong P. Ultrasoundassisted enzymatic hydrolysis of broken Riceberry rice for sugar syrup production as a substrate for bacterial cellulose facial mask development. J Appl Biol Biotech 2022; 10(02):96-101. 